\title{
Factors affecting consumption of retail milk in Chile
}

\author{
Einar Vargas-Bello-Pérez ${ }^{1,2 *}$, Daniel Enríquez-Hidalgo?', \\ Paula Toro-Mujica', María Angélica Fellenberg', \\ Rodrigo A. Ibáñez', Berta Schnettler ${ }^{3,4}$
}

\begin{abstract}
'Pontificia Universidad Católica de Chile, Departamento de Ciencias Animales, Casilla 306. C.P. 6904411, Santiago, Chile 2University of Copenhagen, Faculty of Health and Medical Sciences, Department of Veterinary and Animal Sciences, Grønnegårdsvej 3, DK-1870 Frederiksberg C, Denmark

${ }^{3}$ Universidad de La Frontera, Facultad de Ciencias Agropecuarias y Forestales, Casilla 54-D, Temuco, Chile

${ }^{4}$ Universidad de La Frontera, Scientific and Technological Bioresource Nucleus (BIOREN-UFRO), Temuco, Chile

${ }^{*}$ Corresponding author/Dopisni autor: E-mail: evargasb@sund.ku.dk
\end{abstract}

\section{Abstract}

The aim of the study was to characterize Chilean consumers of commercial fluid milk and determine if sociodemographic characteristics, knowledge and/or perception on nutritive components of milk affect its consumption. A face-to-face interview was conducted through a stratified random sampling with 501 persons in the Province of Santiago, Metropolitan Region, Chile. The interviews were conducted at the entrance of major supermarkets from 5 different municipalities of the Province of Santiago. Interviews were performed from 10.00 h a.m to 13.00 h p.m. and from 15.00 hours to 17.30 h p.m. every day. Sixteen percent of respondents declared not consuming milk due to animal cruelty followed by self-reported lactose intolerance among other reasons. The most consumed types of milk were whole (25\%), semi-skimmed ( $24 \%$ ) and skimmed ( $25 \%)$ followed by other types. The majority of respondents that consume milk declared to do it at home ( $93 \% ; n=393)$, while the rest $(7 \% ; n=30)$ declared to consume milk elsewhere (at a coffee shop, restaurant, as a guest, etc.). Participants declared to make their purchase by prioritizing price followed by brand, type of milk, expiration date, nutritional information, packaging, and milk origin. Respondents (86 \%) declared to know some nutritional benefits from drinking milk: $47.6 \%$ said that milk was important due to its mineral supply, followed by supply of vitamins (17\%), proteins (17.1\%), fat (13.5\%), sugars (4.5\%) and other components (0.4\%). Most of the answers were associated in some degree with sociodemographic factors. Overall, women declared to consume more skimmed milk whereas, males declared to consume in first place whole milk. Respondents between 18-35 years old declared to consume skimmed and whole milks, while respondents with more than 55 years declared to consume fortified milk followed by semi-skimmed. Consumption of skimmed milk was higher in the high-income socioeconomic class whereas the low-income socioeconomic class resulted in higher consumption of whole milk.

Key words: consumption, dairy, Chile, knowledge, fluid milk 


\section{Introduction}

Due to its nutrient contents, milk is an important food at every stage of human life (Ates and Ceylan, 2010) and as a food matrix is an important source of protein, lipids, carbohydrates, minerals and vitamins (Tunick and Van Hekken, 2015). In addition, milk and dairy products can promote health benefits. For example, in a dose-response meta-analysis of observational studies it was suggested to play a possible role for dairy foods, particularly yogurt, in the prevention of type 2 diabetes (Gijsbers et al., 2016).

Consumption of milk and dairy products varies widely among geographical regions. For example in Finland annual milk consumption is around 180 kg per capita whereas in Japan and China is less than $50 \mathrm{~kg}$ (Haug et al., 2007). In Chile, per capita annual milk consumption is approximately $150 \mathrm{~kg}$ and is continuously increasing (ODEPA, 2017). This illustrates the need for studies of consumer behaviour since current market situation has put consumer into a position of major decisive and leading element on market development. Latin American consumers' information on milk consumption has not been well-studied (Possa et al., 2017). Current literature on consumer attitudes towards milk consumption originates mainly from Europe (Villegas et al., 2009; Holmberg and Thelin, 2013; Chollet et al., 2014; Kurajdova and Taborecka-Petrovicova, 2015) and North America (Pieper et al., 2016; McCarthy et al., 2017). Milk consumption studies are relevant for the public health sector since milk and dairy products are of common exposure and availability and even a small change can result in a large population impact (Wang et al., 2018).

According to Pieper et al. (2016), consumer attitudes about food are associated with their knowledge about industry. Factors affecting that knowledge and attitudes are age, gender, education level, place of residence and other factors such as whether or not consumer has children. Thus, our objective was to characterize Chilean consumers of commercial fluid milk and determine if sociodemographic characteristics, knowledge and/or perception on nutritive components of milk affect its consumption. Data from the present study will be useful for the Chilean dairy industry to understand and identify how effective is the dairy market on positioning fluid milk, and also this information can help in dairy beverage innovation and public policy makers.

\section{Materials and methods}

\section{Participants, questionnaires and locations}

This study was conducted in accordance with the guidelines laid down by the Declaration of Helsinki and all procedures involving human subjects were approved by the Ethics Committee (Comité Ético Científico de Ciencias Sociales, Artes y Humanidades) from the Pontificia Universidad Católica de Chile (Protocol ID 150428001, approved in May 2015). Participants (adults) were informed about the study verbally and by a written document before answering the questionnaire, and responding to the questionnaire was regarded as consent for study participation. Since no personally identifiable information such as name or mailing address was collected, all collected data were anonymous. A questionnaire was used as the instrument for collecting information. The questionnaire was created according to the objectives of the present study and was not used previously in other studies. Before using the final questionnaire, a pilot interview was performed on 20 persons at the metro station of San Joaquín in Santiago, Chile. A face-to-face interview was conducted through a stratified random sampling on 501 persons from the Province of Santiago, Metropolitan Region, Chile.

Fourteen questions regarding milk consumption were formulated and presented to consumers. Next to the questions related to milk consumption, the following sociodemographic information about the persons interviewed was recorded: age, gender, and educational level (Table 1). The question "Do you consume milk?" was considered a dichotomous variable. If the answer was "yes", the participant was asked to complete the entire interview; if the answer was "no", the participant was asked to answer the question "Why you do not consume milk?" The sample size was calculated considering a confidence interval of $95 \%$ and an estimation error of $5 \%$ with a $p$ value of 0.5 and a q value of 0.5 . The 
interview was conducted by the same person at the entrance of major supermarkets from 5 different municipalities (population ranges from 112800 to 463103 inhabitants) of the Province of Santiago between $1^{\text {st }}$ of June to $30^{\text {th }}$ of July 2015 . Interviews (approximately 28 per day) were carried out from 1000 hours to 1300 hours and from 1500 hours to 1730 hours (Tuesday-Sunday). Municipalities were selected to represent the main socioeconomic classes from Chile.

TABLE 1. Milk consumption questionnaire

\begin{tabular}{|c|c|}
\hline Question & Answers \\
\hline \multicolumn{2}{|l|}{ Consumption } \\
\hline (1) Do you consume milk? & Yes/no \\
\hline (2) Why you do not consume milk? & $\begin{array}{l}\text { Animal cruelty/lactose intolerance/vegetarian/ } \\
\text { negative media/too expensive/do not like }\end{array}$ \\
\hline (3) How often do you have a glass of milk (200 mL)? & $\begin{array}{l}\text { Daily/three times per week/once per week/once } \\
\text { per month }\end{array}$ \\
\hline (4) What type of milk you consume? & $\begin{array}{l}\text { Whole/semi-skimmed/skimmed/flavored/fortified/ } \\
\text { non-lactose/milk powder/fermented/non-dairy }\end{array}$ \\
\hline (5) Where do you consume milk? & At home/Coffee shop/restaurant/as a guest \\
\hline $\begin{array}{l}\text { (6) What is the most important characteristic that } \\
\text { influence your milk consumption? }\end{array}$ & Flavor (taste)/homogeneity/odor/color \\
\hline
\end{tabular}

\section{Purchase behavior}

(7) At your household, who buys the milk? Mother/father/child/housekeepers/other persons

(8) Prioritize the following items that you consider when purchasing milk

(9) Do you read the labelling? Nutritional information/brand/expiration date/ packaging/price/milk origin

(10) From the labeling, which information is most important for you?

Yes/no

\section{Knowledge and perception}

Expiration date/nutritional information/product description/milk origin/type of production

(11) Do you know that drinking milk could cause $\quad$ Yes/no positive effects for your health?

(12) Which of the following milk nutrients is more important for you?

(13) Do you know about the pasteurization and

Minerals, vitamins, proteins, fat, sugars and other components (i.e., immunoglobulins)

UHT process?

(14) Do you know about the whole milk production process?

\section{Statistical analysis}

Interviews were subjected to an exploratory descriptive analysis of categorical variables. Initial statistical test on the data was performed by two-dimensional contingency tables from which percentages, frequencies and distributions were obtained from each question. Statistical frequency was analyzed using the Chi-squared test. The SPSS statistical package was used. Significance was declared at $\mathrm{P}<0.05$.

\section{Results and discussion}

To our knowledge, the present study is the first report on the characterization of Chilean consumers of commercial fluid milk. In urban areas, low consumption of milk is most likely related to low consumer demand (Hendijani and Karim, 2010). Therefore, it is important to improve the knowledge about the factors stimulating and/or influencing consumers when purchasing milk, in order to encourage their consumption. It is also imperative to study those factors that prevent consumers in their 
purchasing and consumption behaviours in order to deal with them and transform such barriers into market opportunities and public policies to increase milk consumption.

TABLE 2. Characteristics of consumers interviewed $(n=501)$ in the Province of Santiago, Chile

\begin{tabular}{|c|c|c|}
\hline Sample & $n$ & $\%$ \\
\hline \multicolumn{3}{|l|}{ Gender } \\
\hline Female & 242 & 48.3 \\
\hline Male & 259 & 51.7 \\
\hline \multicolumn{3}{|l|}{ Age (years) } \\
\hline $18-25$ & 225 & 44.9 \\
\hline $26-35$ & 119 & 23.8 \\
\hline $36-45$ & 89 & 17.8 \\
\hline $46-55$ & 47 & 9.4 \\
\hline$>55$ & 21 & 4.2 \\
\hline \multicolumn{3}{|c|}{ Education (highest level) } \\
\hline Primary school & 23 & 4.6 \\
\hline High school & 176 & 35.1 \\
\hline Technical & 108 & 21.6 \\
\hline University & 194 & 38.7 \\
\hline \multicolumn{3}{|c|}{ Socioeconomic classes (Family income per month; $\$$ USD*) } \\
\hline $\mathrm{ABC} 1:>2500$ & 110 & 22.0 \\
\hline C2: $900-1700$ & 53 & 10.6 \\
\hline C3: $600-700$ & 204 & 40.7 \\
\hline D: $300-400$ & 50 & 10.0 \\
\hline $\mathrm{E}: \leq 240$ & 84 & 16.8 \\
\hline
\end{tabular}

*Socioeconomic classes were selected according to Adimark (2004); Approximate income expressed in \$USD (October 2017).

In general, the distribution of participants among different demographic categories in this study was similar to previous reports (Table 2). A higher proportion of women than men were interviewed, which reflects that, in Chile, women are more likely to conduct market shopping than men, which was also observed in interviews focused on cheese consumption (Vargas-Bello-Pérez et al.,
2014) in undeveloped countries and in meat (Verbeke and Vackier, 2004) and cheese purchases (Mesias et al., 2003) in developed countries. In that sense, generally women are the most valuable target audience for the food industry, since they have the largest responsibility for food purchasing (Childs, 1998).

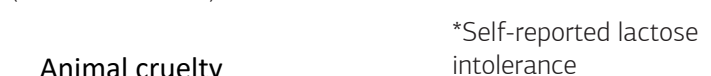

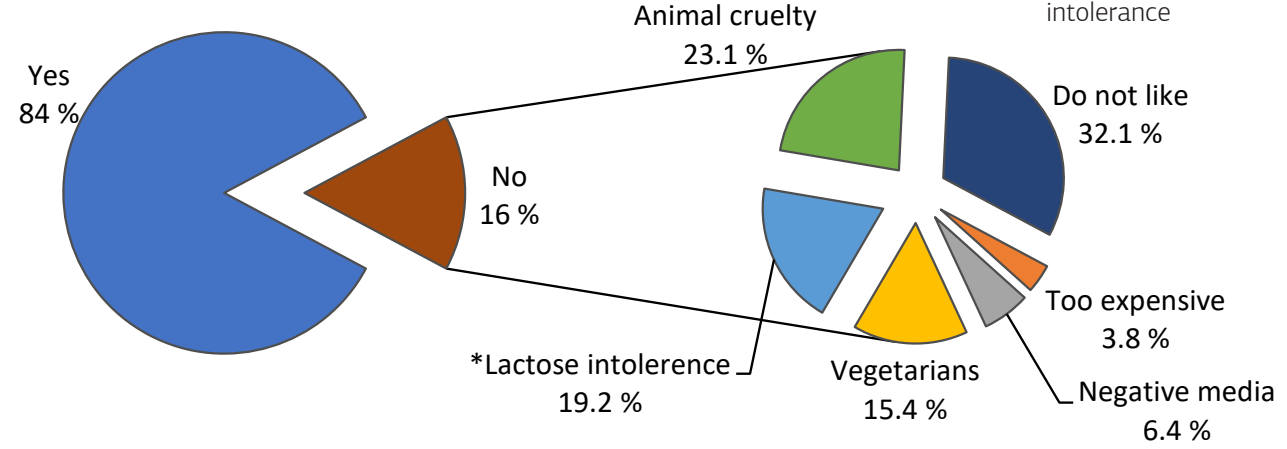

FIGURE 1. Reasons for not consuming retail fluid milk in the Province of Santiago 


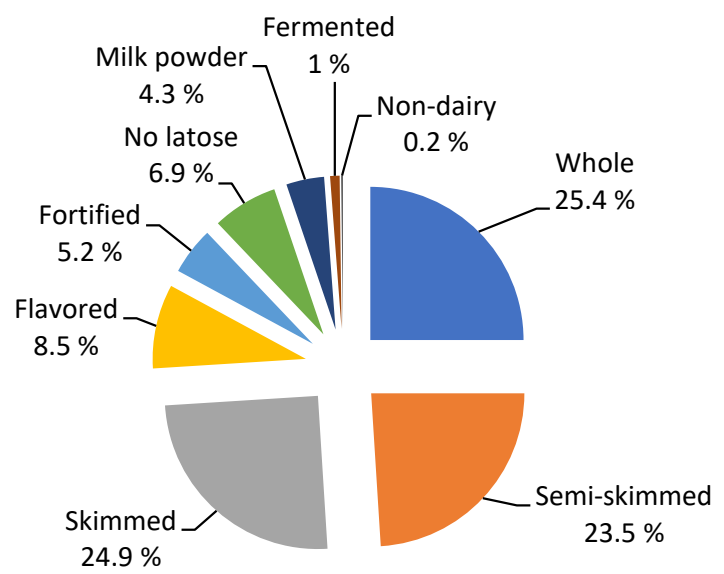

FIGURE 2. Types of milk consumed in the Province of Santiago

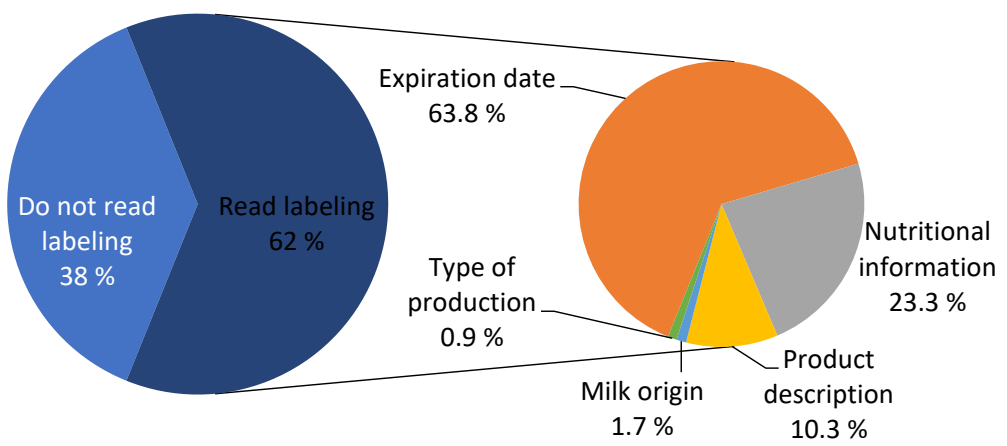

FIGURE 3. Important labelling information for milk consumers of the Province of Santiago

\section{Consumption}

Sixteen percent $(n=78)$ of respondents declared not to consume milk which was associated [Xi $(20)^{2}$, 53,465, $P<0.001]$ with socioeconomic classes. The main reason for was animal cruelty followed by self-reported lactose intolerance among other reasons (Figure 1). Today, there are several critics of the animal production systems and they are based on cruel and inhumane practices (Hsiao, 2017; Vargas-Bello-Pérez et al., 2017). Another reason that hinders milk consumption were nutritional recommendations, for example, lactose intolerance and the cholesterol content of milk were identified as two major factors (Prado et al., 2008) related to the decrease in milk consumption and the development and production of non-dairy beverages.

Milk consumption was related with socioeconomic class [Xi $\left.(4)^{2}, 23,177, P<0.001\right]$. From all respondents, the social class $E$ (the lowest income per month) resulted to have the higher percentage (94\%) whereas class C2 resulted to have the lowest
(64\%) milk consumption. According to the Chilean government, the social class $\mathrm{E}$ is a group that prioritize quantity and flavour rather than body weight control (ODEPA, 2009). Educational level was related to milk consumption as well $\left[\mathrm{xi}(3)^{2}, 10,359\right.$, $\mathrm{P}=0.016]$. Respondents with high school education declared to consume more milk (91.5\%) followed by those with university education, technical education and primary school education (84.4\%). These results agree with a face-to-face interview to Turkish households done by Ates and Ceylan (2010); they reported that the main factors affecting milk, yoghurt and cheese consumption included socio-economic and general demographic factors.

\section{Type of milk consumed}

The most consumed milk types were whole (25\%), semi-skimmed (24\%) and skimmed (25\%) followed by other types (Figure 2). Gender [Xi $(8)^{2}$, 32,337, $P<0.001$ ], age [Xi $\left.(32)^{2}, 89,648, P<0.001\right]$, socioeconomic class [Xi $\left.(32)^{2}, 166,733, P<0.001\right]$ 
and educational level [Xi $(24)^{2}, 50,071, P=0.001$ ] were factors related to the type of milk consumed. Women declared to consume more skimmed milk (60.4\%), than other types of milk such as fortified (14.1\%), non-lactose (18.9\%), powdered milk (2.8\%) and fermented (3.8\%). On contrary, male respondents declared to consume in first place whole milk (44.1\%), followed by semi-skimmed milk (38.2 \%), flavoured (17.1\%) and non-dairy beverages (0.7\%). Respondents between 1825 years old declared to consume in first place skimmed milk followed by semi-skimmed and whole milk, while respondents between 26-35 years old declared to consumed whole and skimmed milks followed by flavoured milk and semi-skimmed milk. Finally, respondents more than 55 years old declared to consume fortified milk followed by semi-skimmed, whole milk and fermented milk. Respondents from socioeconomic class C3 (middle class) declared to consume more $(P<0.001)$ semi-skimmed milk (30\%), less $(P<0.001)$ whole milk (17.7\%) and non-lactose (2.9\%) than the rest of the social classes. The highest consumption of whole milk (44.9\%) and powdered milk (12.8\%) was observed in class $\mathrm{E}$, and this socioeconomically class was found to present less consumption of skimmed milk (10.3\%) and flavour milk (1.3\%). Consumption of flavoured milk (15.5\%) and skimmed milk $(34.02 \%)$ was significantly higher $(\mathrm{P}<0.001)$ than the other options in class $A B C 1$. In terms of education level, respondents with primary school $(11.1 \%)$, preferred $(\mathrm{P}<0.001)$ cultivated milk and those with university education preferred $(P<0.001)$ fortified milk (10.2\%). Consumption of non-lactose milk was lower in those respondents with university education (3.2 \%). Education level was not associated with the consumption of whole milk, semiskimmed milk, skimmed milk, powdered milk and vegetable milk-like beverages.

Our data on type of milk consumed agrees with previous studies where fat content is one of the most important motivators for consuming fat-reduced dairy products (Johansen et al., 2011). In the present study $75 \%$ of interviewed individuals consumed fat-reduced milk along with other products such as flavoured milk, fortified milk, powdered milk and lactose-free milk. Such findings were in concordance with Chollet et al. (2014), who studied dairy consumption among adults in Switzerland and reported that $53 \%$ of respondents declared to consume fat-reduced products mainly to reduce fat and calories consumption. Also, the presented data were in concordance with Bus and Worsley (2003) and Johansen et al. (2011) who reported that consumption of full-fat milk in women was lower than that of men, and those authors proposed that women focus much more on fat content and weight control than men. According to Keast and Lau (2006), consumer quality perception consists of different variables that include taste, healthfulness and safety. An online interview (McCarthy et al., 2017) about drivers of choice for fluid milk in the United States reported that milk consumers associated their health status to fewer calories, less fat and less carbohydrates.

\section{Consumption and purchase behaviors}

The majority of respondents that consume milk declared to do it at home (93\%; $n=393$ ), while the rest ( $7 \%$; $\mathrm{n}=30$ ) declared to consume milk elsewhere (at a coffee shop, restaurant, as a guest, etc.). From the individuals interviewed that declared to buy fluid milk, some member of their household performed the purchase of milk. The following household members distributed milk purchase: $47 \%$ $(\mathrm{n}=219)$ was done by the mother, $18 \%(\mathrm{n}=84)$ by a child, $15 \%(n=70)$ by the father, $8 \%(n=37)$ by the housekeeper and $12 \%(n=55)$ by other persons. This consumption behaviour related to the place of consumption and main purchaser of fluid milk of the household was similar to that of the Chilean cheese consumers previously reported by Vargas-Bello-Pérez et al. (2014). In terms of milk consumption frequency, $44 \%$ ( $n=186)$ of interviewed individuals consumed milk daily, $30 \%(n=127)$ three times per week, $19 \%(n=80)$ once per week and $7 \%(n=30)$ once per month. Age, gender, socioeconomic class and educational level $(P>0.05)$ did not affect milk consumption frequency.

Respondents declared that flavour (taste) was the main (84\%; $n=355)$ characteristic that influenced their milk consumption followed by homogeneity ( $9 \% ; n=38)$, odour ( $5 \% ; n=21)$ and colour (2\%; $n=8)$. These characteristics were related to sociodemographic classes [Xi $(12)^{2}, 53,884$, $\mathrm{P}<0.001$ ]. Social classes $A B C 1$ (upper class) and C2 were more attracted by colour. The middle class 
(C3), ABC1, C2 and D were more attracted to odour and homogeneity and the $\mathrm{E}$ (lowest income class) was more appealed by flavour. This study agrees with a previous Australian study (Bus and Worsley, 2003) reporting that the majority of respondents agreed that milk has good sensory properties and this might be associated to the fact that taste is the utmost determinant of food choice (Asioli et al., 2017).

The interviewed participants declared to make their purchase by prioritizing price followed by brand, type of milk, expiration date, nutritional information, packaging, and milk origin. The majority of milk consumers ( $62.7 \% ; n=116)$ indicated that they use to read the labelling before purchasing and this behaviour was related to socioeconomic class [Xi (4)2, 9,920, P=0.042] and gender [Fisher (1), 4,965, $P=0.019]$. Socioeconomic class $E$ showed the highest percentage $(71 \%)$ of respondents that claimed to read the labelling while women showed the highest percentage (67\%) for labelling reading. Expiration date was the most important item that was read from the label followed by nutritional information, product description, milk origin and type of production (Figure 3). These findings somehow agree with Cornick et al. (1994) who reported that household income, household composition and education are factors that influence purchase of fluid milk. Also, in a Czech study (Hrubá, 2016), it was indicated that intension of buying from a particular processor is positively associated with the place of origin of milk, safety, as well as with information about how food is produced.

Despite the fact that in the Chilean market there is no grass-fed dairy labelling available, there is some popular association (and belief that milk from grass-fed animals is more healthy) between milk produced from Southern companies and grazing production systems. Some proportion of the respondents indicated that the type of production was the main item they use to read when purchasing milk, which may be related to previously described consumer beliefs. A similar example of dairy consumer-purchase behaviour is the study by Faletar et al. (2016) who reported a significant and positive influence on buying intention of organic milk and this was related to the belief in positive aspects of organic milk, subjective knowledge, objective knowledge, and attitude towards buying organic milk.

\section{Knowledge and perception}

Educational level affects consumption, especially with respondents with university degree who also showed to have more knowledge on the nutritional components of milk. Respondents (86\%) declared to know some nutritional benefits from drinking milk: $47.6 \%$ said that milk was important due to its mineral supply, followed by supply of vitamins (17\%), proteins (17.1\%), fat (13.5\%), sugars $(4.5 \%)$ and other components (0.4\%). The awareness that milk is a good source of calcium is consistent with previous studies (Bus and Worsley, 2003). In fact, consumers are generally conscious about the importance of milk for bone health (Harel et al., 1998).

Only $40.5 \%$ declared to know about the process of pasteurization and UHT, which was associated with their educational level $\left[\mathrm{Xi}(3)^{2}, 22,595\right.$, $\mathrm{P}<0.001]$. Approximately $54 \%$ had university degree followed by primary school, high school and technical education. Recently, Liem et al. (2016) studied the influence of labelling on Australian and Chinese consumers' liking of milk with short (pasteurized) and long (UHT) shelf life and found that Australians preferred the taste of pasteurized milk over the taste of UHT milk whereas Chinese participants preferred the taste of UHT milk over the taste of pasteurized milk.

Regarding the knowledge on milk production process ('from farm to fork'), $41.5 \%$ expressed to know the milk production process, which was associated with age $\left[\mathrm{Xi}(4)^{2}, 13,014, P=0.011\right]$ and educational level [Xi (3) $\left.{ }^{2}, 17,476, P=0.001\right]$. Most respondents who declared to know the production process were 18-25 (48.9\%) and more than 55 (38 $\%)$ years old. Interestingly, knowledge on milk production process was not related to milk consumption [Fisher (1), 0,163, $\mathrm{P}=0.709$ ] nor to milk purchase [Fisher (1), 0,170, P=0.708]. There was an association between the knowledge of the milk production process and the age [Xi (4)2, 13,014, $P=0.011]$, socioeconomic class [Xi (4)2, 51,209, $P<0.001]$ and level of education [Xi (3)2, 17,476, $P=0.001]$ of the respondents. Respondents between 18 to 25 years of age, socioeconomic classes E, followed by $D$ and C2 and participants with university degree claimed to have more knowledge on milk production. 


\section{Conclusion}

The most consumed types of milk were whole, semi-skimmed and skimmed followed by other types. Women declared to consume more skimmed milk whereas, males declared to consume in first place whole milk. Respondents between 18-35 years old declared to consume skimmed and whole milks, while respondents with more than 55 years declared to consume fortified milk followed by semi-skimmed. Consumption of skimmed milk was higher in the high-income socioeconomic class whereas the low-income socioeconomic class resulted in higher consumption of whole milk. Overall, respondents between 18 to 25 years old within lowand medium- income socioeconomic classes with university degree claimed to have more knowledge on milk production. Our data could be beneficial not only for Chile but also for other Latin American countries or other places with similar conditions. In addition, our data could help to increase the currently low consumption of milk and milk products to a more satisfactory level in the country and our findings may be beneficial to public policy makers.

\section{Acknowledgment}

The authors thank Elizabeth Huenul for collecting all data. This research received no specific grant from any funding agency, commercial or notfor-profit sectors.

\section{Čimbenici koji utječu na potrošnju konzumnog mlijeka u Čileu}

\section{Sažetak}

Cilj ovog rada bio je okarakterizirati potrošače konzumnog mlijeka u Čileu i utvrditi jesu li sociodemografske karakteristike, znanje i/ili percepcija nutritivnih komponenti mlijeka utjecale na njegovu potrošnju. Intervju metodom licem u lice proveden je primjenom slojevitog slučajnog uzorkovanja na 501 osobi u provinciji Santiago, Metropolitan Region, Čile. Istraživanja su provedena na ulazu u glavne supermarkete na području 5 različitih općina u provinciji Santiago. Ispitanici su svaki dan anketirani u razdoblju od 10:00 do 13:00 sati te od 15:00 sati do 17:30 sati. $16 \%$ ispitanika izjavilo je da ne konzumira mlijeko zbog okrutnosti nad životinjama, a potom i zbog netolerancije laktoze među ostalim razlozima. Najčešće konzumirane vrste mlijeka bile su punomasno (25\%), polumasno (24\%) i obrano (25\%), a slijede druge vrste. Većina ispitanika koji konzumiraju mlijeko priopćila je da to radi kod kuće, a ostali su deklarirali da konzumiraju mlijeko i na drugim mjestima poput kafića, restorana, u kućnim posjetama itd. Ispitanici su izjavili da odabir mlijeka provode prije svega obzirom na cijenu, ali i obzirom na robnu marku, vrstu mlijeka, datumu isteka, prehrambenim informacijama, pakiranjem i podrijetlom. Ispitanici (86 \%) su izjavili kako poznaju neke prehrambene koristi povezane s konzumacijom mlijeka - 47,6 \% je reklo da je mlijeko važan izbor mineralnih tvari, a zatim i izvor vitamina (17 \%), proteina (17,1\%), masti (13,5\%), šećera (4,5\%) i ostalih sastojaka (0,4 \%). Većina odgovora bila je u određenoj mjeri povezana sa socio-demografskim čimbenicima. Ispitanici starosne skupine 18-35 godina su izjavili da uglavnom konzumiraju obrano i punomasno mlijeko, dok su ispitanici stariji od 55 godina uglavnom konzumirali obogaćeno i polumasno mlijeko. Konzumacija obranog mlijeka bila je veća među stanovništvom boljeg imovinskog statusa dok je konzumacija punomasnog mlijeka zastupljenija među stanovništvom lošijeg socioekonomskog statusa.

Ključne riječi: konzumacija, mliječni proizvodi, Čile, znanje, konzumno mlijeko 
1. Adimark (2004): Mapa socioeconómico de Chile. http://www.adimark.cl/medios/estudios/informe_mapa_ socioeconomico_de_chile.pdf (accessed January 2018)

2. Asioli, D., Varela, P., Hersleth, M., Lengard Almli, V., Veflen Olsen, N., Næs, T. (2017): A discussion of recent methodologies for combining sensory and extrinsic product properties in consumer studies. Food Quality and Preference 56, 266-273. https://doi.org/10.1016/j.foodqual.2016.03.015

3. Ates, H., Ceylan, M. (2010): Effects of socio-economic factors on the consumption of milk, yoghurt, and cheese. British Food Journal 112 (3), 234-250. https://doi.org/10.1108/00070701011029110

4. Bus, A., Worsley, A. (2003): Consumers' sensory and nutritional perceptions of three types of milk. Public Health Nutrition 6 (2), 201-208. https://doi.org/10.1079/PHN2002417

5. Childs, N.M. (1997): Foods that help prevent disease: consumer attitudes and public policy implications. Journal of Consumer Marketing 14 (6), 433-447. https://doi.org/10.1108/07363769710186015

6. Chollet, M., Gille, D., Piccinali, P. (2014): Short communication: dairy consumption among middle-aged and elderly adults in Switzerland. Journal of Dairy Science 97 (9), 5387-5392. https://doi.org/10.3168/jds.2014-8193

7. Cornick, J., Cox, T., Gould, B. (1994): Fluid milk purchases: a multivariate Tobit analysis. American Journal of Agricultural Economics 76 (1), 74-82. https://doi.org/10.2307/1243922

8. Faletar, I., Cerjak, M., Kovačić, D. (2016): Odrednice stava i namjere kupnje ekološkog mlijeka Mljekarstvo 66 (1), 59-65. https://doi.org/10.15567/mljekarstvo.2016.0106

9. Gijsbers, L., Ding, E.L., Malik, V.S., de Goede, J., Geleijnse, J.M., Soedamah-Muthu, S.S. (2016): Consumption of dairy foods and diabetes incidence: a dose-response metaanalysis of observational studies. American Journal of Clinical Nutrition 103 (4), 1111-1124. https://doi.org/10.3945/ajcn.115.123216

10. Harel, Z., Riggs, S., Vaz, R., White, L., Menzies G. (1998): Adolescents and calcium: What they do and do not know and how much they consume. Journal of Adolescent Health 22 (3), 225-228. https://doi.org/10.1016/S1054-139X(97)00174-2

11. Haug, A., Hostmark, A.T., Harstad, O.M. (2007): Bovine milk in human nutrition - a review. Lipids Health and Disease 6 (25). https://dx.doi.org/10.1186\%2F1476-511X-6-25

12. Hendijani, B.R., Ab Karim, M.S. (2010): Factors affecting milk consumption among school children in urban and rural areas of Selangor, Malaysia. International Food Research Journal 17, 651-660.

13. Holmberg, S., Thelin, A. (2013): High dairy fat intake related to less central obesity: a male cohort study with 12 years' follow-up. Scandinavian Journal of Primary Health Care 31 (2), 89-94. https://dx.doi.org/10.3109\%2F02813432.2012.757070
14. Hrubá, R. (2016): Behavior of agents at food market, especially asymmetric information on the Dairy Market. Journal of Applied Economics and Business Research 6 (1), 36-54.

15. Hsiao, T. (2017): Industrial farming is not cruel to animals. Journal of Agricultural and Environmental Ethics 30 (1), 37-54. https://doi.org/10.1007/s10806-017-9652-0

16. Johansen, S.B., Naes, T., Hersleth, M. (2011): Motivation for choice and healthiness perception of calorie-reduced dairy products. A cross-cultural study. Appetite 56 (1), 15-24. https://doi.org/10.1016/j.appet.2010.11.137

17. Keast, R.S.J., Lau, J.J. (2006): Culture-specific variation in the flavor profile of soymilks. Journal of Food Science 71, S567-S572. https://doi.org/10.1111/j.1750-3841.2006.00146.x

18. Kurajdova, K., Táborecka-Petrovicova, J. (2015): Literature review on factors influencing milk purchase behavior. International Review of Management and Marketing 5 (1), 9-25.

19. Liem, D.G., Bolhuis, D.P., Hu, X., Keast, R.S.J. (2016): Short communication: Influence of labeling on Australian and Chinese consumers' liking of milk with short (pasteurized) and long (UHT) shelf life. Journal of Dairy Science 99 (3), 1747-1754. https://doi.org/10.3168/jds.2015-10516

20. McCarthy, K.S., Parker, M., Ameerally, A., Drake, S. L., Drake, M.A. (2017): Drivers of choice for fluid milk versus plantbased alternatives: What are consumer perceptions of fluid milk?. Journal of Dairy Science 100 (8), 6125-6138. https://doi.org/10.3168/jds.2016-12519

21. Mesias, F., Escribano, M., Rodríguez, A., Pulido, F. (2003): Market segmentation of cheese consumers: an approach using consumer's attitudes, purchase behavior and socio demographic variables. International Journal of Dairy Technology 56 (3), 149-155. https://doi.org/10.1046/j.1471-0307.2003.00092.x

22. ODEPA. Oficina de Estudios y Políticas Agrarias. (2009): Percepción de los consumidores sobre productos hortofrutícolas, lácteos, carnes y pan. http://www.odepa.cl/wp-content/files mf/1369754044Estudio_percepcion_de_los_ consumidores.pdf (accessed January 2018).

23. ODEPA. Oficina de Estudios y Políticas Agrarias. (2017): http://www.odepa.cl/rubro/leche-y-derivados/ (accessed January 2018).

24. Pieper, L., Doherr, M.G., Heuwieser, W. (2016): Consumers' attitudes about milk quality and fertilization methods in dairy cows in Germany. Journal of Dairy Science 99 (4), 3162-3170. https://doi.org/10.3168/jds.2015-10169

25. Possa, G., Castro, M.A.D., Sichieri, R., Fisberg, R.M., Fisberg, M. (2017): Dairy products consumption in Brazil is associated with socioeconomic and demographic factors: Results from the National Dietary Survey 2008-2009. Revista de Nutrição 30, 79-90. http://dx.doi.org/10.1590/1678-98652017000100008 
26. Prado, F.C., Parada, J.L., Pandey, A., Soccol, C.R. (2008): Trends in non-dairy probiotic beverages. Food Research International 41 (2), 111-123.

https://doi.org/10.1016/j.foodres.2007.10.010

27. Tunick, M.H. Van Hekken, D.L. (2015): Dairy products and health: recent insights. Journal of Agricultural and Food Chemistry 63 (43), 9381-9388. https://doi.org/10.1021/jf5042454

28. Vargas-Bello-Pérez, E., Aguilar, C., Toro-Mujica, P., Vera, R., Cerda, M., Briones, I. (2014): Characterization of cheese consumers in Santiago Province, Chile. Ciencia e Investigacion Agraria 41 (3), 327-335. http://dx.doi.org/10.7764/rcia.v41i3.1392

29. Vargas-Bello-Pérez, E., Miranda-de la Lama, G.C., Teixeira, D.L., Enríquez-Hidalgo, D., Tadich, T., Lensink, J. (2017): Farm animal welfare influences on markets and consumer attitudes in Latin America: the cases of Mexico, Chile and Brazil. Journal of Agricultural and Environmental Ethics 30 (5), 697-713.

https://doi.org/10.1007/s10806-017-9695-2
30. Verbeke W \& Vackier I (2004): Profile and effects of consumer involvement in fresh meat. Meat Science 67 (1), 159-168.

https://doi.org/10.1016/j.meatsci.2003.09.017

31. Villegas, B., Carbonell, I., Costell, E. (2009): Acceptability of milk and soymilk vanilla beverages. Demographics consumption frequency and sensory aspects. Food Science and Technology International 15 (2), 0203-210. https://doi.org/10.1177\%2F1082013208105166

32. Wang, S., Zhou, M., Ji, A., Zhang, D., He, J. (2018): Milk/ dairy products consumption and gastric cancer: an update meta-analysis of epidemiological studies. Oncotarget 9 (6), 7126-7135.

https://doi.org/10.18632/oncotarget.23496 